\title{
Molecular Detection of Rabies by SYBR Green Real Time PCR
}

\author{
A Kaw ${ }^{1}$, C K Singh ${ }^{2}$, B S Sandhu ${ }^{3}, \mathrm{~K} \mathrm{Bansal}^{4}$, N K Sood ${ }^{5}$ \\ 1,2,3,4,5 Department of Veterinary Pathology, College of Veterinary Sciences, Guru Angad Dev Veterinary and \\ Animal Sciences University, Ludhiana-141004, India
}

\begin{abstract}
The present study was envisaged to compare the sensitivity of SYBR Green real time PCR with immunofluorescence PCR for diagnosis of rabies. SYBR Green real time PCR technique was applied on brain samples collected from 39 rabies suspected animals. Sensitivity of SYBR Green technique was compared in accordance with WHO recommended gold standard test viz. Fluorescent Antibody Technique (FAT) applied on brain samples. SYBR Green real time PCR applied on brain samples had successfully confirmed rabies in 16/39 with a Sensitivity of $80 \%$. It was concluded that SYBR Green real time PCR is a useful, specific, sensitive and better molecular approach for diagnosis of rabies from brain of rabid suspected cases and can be used as confirmatory test for rabies diagnosis.
\end{abstract}

Keywords: Brain, Molecular, Rabies, Real time PCR, SYBR Green.

\section{INTRODUCTION}

Rabies is enzootic and is a serious public health and economic problem in India. A national survey by the Association of the Prevention and Control of Rabies APCRI, 2003 estimated that in India a total of 18,500 human deaths occur as a result of rabies each year. Although the loss of livestock due to rabies is significant, there are few publications on estimates of the incidence of rabies in livestock [1]. Molecular approaches like RT- PCR and real-time PCR seem to be more reliable and more sensitive than traditional methods used for rabies diagnosis $[2,3,4]$. They allow for the detection of genetic material of viruses in a relatively short time. The present study was conducted to study the efficacy of SYBR Green real time PCR for detection of rabies in brain tissue samples.

\subsection{Source of brain specimens}

\section{MATERIALS AND METHODS}

39 brain samples from different animal species, all suspected of rabies, previously diagnosed by FAT and stored as $10 \%$ homogenate in phosphate buffered saline at $-20^{\circ} \mathrm{C}$ were obtained. Lyophilized anti rabies vaccine was used as positive control and brain of normal animal that had natural death was used as negative control.

\subsection{RNA extraction and cDNA synthesis}

Total RNA in the brain specimens, positive and negative controls was extracted using Qiazol (Qiagen, USA) according to the manufacturer's instructions. The RNA was stored at $-80^{\circ} \mathrm{C}$ until further use. The RNA was subjected to cDNA synthesis using a primer RabN1 (TABLE 1) and subjected to $65^{\circ} \mathrm{C}$ for $10 \mathrm{~min}$, followed by $37^{\circ} \mathrm{C}$ for $15 \mathrm{~min}$, chilled on ice and briefly spun down. Reverse transcriptase (Qiagen, USA) mix was prepared and subjected to conditions $37^{\circ} \mathrm{C}$ for $2 \mathrm{~h}, 95^{\circ} \mathrm{C}$ for $5 \mathrm{mins}$ and chilling on ice for 5 mins in a thermal cycler (Eppendorf). This cDNA was used for amplification in real time PCR assay in this study. Considering that the $\mathrm{N}$ gene is the most conserved in the Lyssaviruses (except some domains of the L protein gene) and that the sequence data concerning this gene are the most exhaustive, we used primers in the $\mathrm{N}$ gene that were shown to allow amplification of a wide range of genetically diverse lyssaviruses [5].

\subsection{SYBR GREEN Real time PCR assay}

The procedure used for the real time PCR was essentially those described earlier by [5] Nagaraj et al., (2006) with minor modifications. The PCR assay was carried out in $25 \mu \mathrm{l} \mathrm{PCR} \mathrm{mixture} \mathrm{volume} \mathrm{consisting} \mathrm{of}$ $12.5 \mu \mathrm{l}$ of SYBR Green master mix (Qiagen, USA) with $1 \mu \mathrm{l}$ of primers O1 and R6 ( $3 \mathrm{pmol} / \mu \mathrm{l})($ Table 1$)$ and 5 $\mu \mathrm{l}$ of the cDNA prepared using RabN1 primer. Amplification was carried out at $55{ }^{\circ} \mathrm{C}$ for $2 \mathrm{~min}, 95^{\circ} \mathrm{C}$ for 10 min, followed by 40 cycles in two steps: $95^{\circ} \mathrm{C}$ for $15 \mathrm{~s}, 60^{\circ} \mathrm{C}$ for $1 \mathrm{~min}$. Amplification, data acquisition and analysis were carried out by using ABI 7500 instrument and ABI prism SDS software. This software coupled to the ABI system determines the cycle threshold $(C \mathrm{t})$ that represents the number of cycles in which the fluorescence intensity is significantly above the background fluorescence. 


\section{Clinical details of animals}

\section{RESULTS AND DISCUSSION}

The salient clinical features of the 39 suspected animals are presented in TABLE 2. Amongst the 39 animals that were included in this study 7 were buffaloes, 10 cows, 20 dogs and 1 each horse and cat.

\section{Real time PCR assay}

For amplification in real time PCR oligonucleotides O1 and R6 (Table 1) were used. A typical amplification plot and melting curve analysis for the determination of the specificity is presented in Fig. 1 and 2 respectively. As can be observed from the (FIG. 1), the cycle threshold $(\mathrm{Ct})$ of the positive control was at the 26th cycle whilst most of the clinical samples had $C t$ values ranging from 26 to 29 cycles. It can be observed from (FIG. 2) that a sharp peak was noted at $78^{\circ} \mathrm{C}$ for the positive control as well as all samples that were positive on or before the 29th cycle. The SYBR Green real time analysis shows that, amongst the 39 samples, 16 samples $(41.02 \%)$ were positive. The sensitivity of this test was $80 \%$ and specificity was 1 . The sensitivity of nested RT-PCR on the same samples was $70 \%$ and specificity was 1 . Thus confirming that real time PCR is more sensitive than conventional PCR.

PCR has become a valuable tool in various laboratories being faster than both the RTCIT and MIT and more sensitive and specific than the FAT. When combined with sequence analysis the sample genotype can be rapidly confirmed and epidemiological analysis undertaken [6]. PCR detection of RV (rabies virus) has been described by a number of investigators $[7,8,9,10]$. We preferred SYBR Green real time assay as the application of this assay was for more sensitive diagnosis of the infection. [11] HuGHES designed a TaqMan PCR based method for detection of rabies virus RNA in tissue samples. The assay was found to be sensitive and specific and correlated well with the concentration of infectious virus but the number of mismatches reduced the efficiency of the reaction such that four differences could result in a weakly positive or negative result. When using SYBR Green it is however necessary to rely on melting curves to ensure that the obtained signal is specific. An advantage of real time PCR is that it is a closed tube system that significantly reduces risk of cross contamination of PCR products and thus results in increased confidence in the results acquired [5].

\section{TABLES}

Table 1: Primers used for Nested RT-PCR

\begin{tabular}{cccc}
\hline Primer Name & $\begin{array}{c}\text { Nucleotide Sequence } \\
\text { 5'-3 }\end{array}$ & Positions & Sense \\
\hline O1 & CTACAATGGATGCCGAC & $66-82$ & + \\
R6 & CCTAGAGTTATACAGGGCT & $201-183$ & - \\
\hline \multicolumn{4}{c}{ Table 2: Clinical features of 39 rabies suspected animals } \\
\hline Clinical feature & $\begin{array}{c}\text { Proportion of animals } \\
\text { (out of 39) }\end{array}$ \\
\hline Fever & 13 \\
Hyper-salivation & 18 \\
Difficult intake & 13 \\
Behavioral change & 22 \\
Off feed & 33 \\
Micturition & 9 & \\
Paralysis & 17 \\
Recognized owner & 17 \\
Vaccination status- nil & 38 \\
-proper & 01 \\
\end{tabular}

\section{FIGURES}

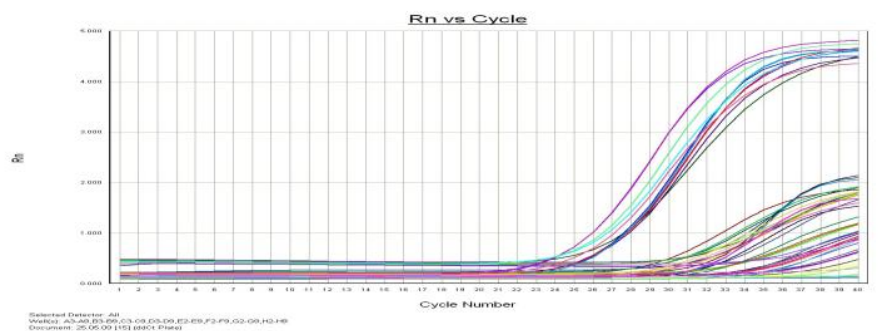

Fig. 1: Graph showing cycle threshold at $26^{\text {th }}$ cycle for positive control and cycle threshold of positive samples ranges between $26-29^{\text {th }}$ cycles. 


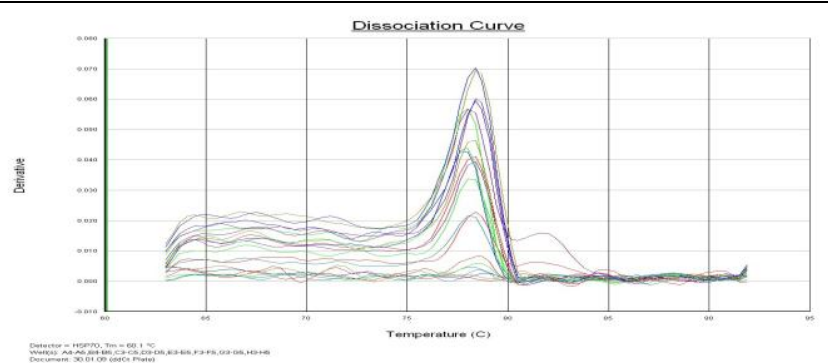

Fig. 2: Graph showing dissociation curve peak at $78^{\circ} \mathrm{C}$. The shallow peaks before $70{ }^{\circ} \mathrm{C}$ represent primer dimer.

\section{CONCLUSION}

Newer, more advanced molecular approaches like SYBR Green real time PCR was applied for the detection of rabies virus in brain tissue specimens of animals. Highest sensitivity was observed with real time PCR than conventional RT-PCR. The results were in concordance with the FAT applied on the impression smears of the same samples. So this technique can be successfully used for the epidemiological study and if combined with sequencing the genotypes prevalent in that area can be identified.

\section{ACKNOWLEDGEMENTS}

Authors are grateful to Dr. A S Nanda, Director of Research, Guru Angad Dev Veterinary and Animal Science University for providing the necessary facilities. The work was conducted in the Government of Punjab sponsored research scheme entitled "Development of Research-cum-Diagnostic laboratory for Rabies". The study relates to the naturally prevalent cases and, thus, does not include any experiments.

\section{REFERENCE}

[1] D. L. Knobel, S. Cleaveland, P. G. Coleman, E. M. Fevre, M. I. Meltzer, M. E. G. Miranda, A. Shaw, J. Zinsstag and F. X. Meslin. Re-evaluating the burden of rabies in Africa and Asia. Bulletin World Health Organisation, 83, 2005, 360-368.

[2] E. M. Black, J. P. Lowings, J. Smith, P. R. Heaton and L. M. McElhimney, L.M. A rapid RT-PCR method to differentiate six established genotypes of rabies and rabies-related viruses using TaqMan technology. Journal of Virological Methods, 105, 2002, 25-35.

[3] E. Picard-Meyer, V. Bruyére, J. Barrat, E. Tissot, M. J. Barrat and F. Cliquet. Development of a hemi-nested RT-PCR method for the specific determination of European Bat Lyssavirus 1. Comparison with other rabies diagnostic methods. Vaccine, 22, 2004, 1921-1929.

[4] P. R. Wakeley, N. Johnson, L. M. McElhinney, D. Marston, J. Sawyer and A. R. Fooks. Development of a real-time, differential RT-PCR TaqMan® assay for lyssavirus genotypes 1, 5 and 6. Development in Biologicals (Basel), 126, 2006, $227-236$.

[5] T. Nagaraj, P. V. Joel, A. Desai, A. Kamat, S. N. Madhusudana and V. Ravi. Ante mortem diagnosis of human rabies using saliva samples: Comparison of real time and conventional RT-PCR techniques, Journal of Clinical Virology, 36, 2006, 17-23

[6] P. R. Heaton, L. M. McElhinney, J. H. A. Bowen-Davies and J. P. Lowings. Heminested PCR assay for detection of six genotypes of rabies and rabies-related viruses, Journal of Virological Methods, 81(1-2), 1999, 63-69.

[7] A. Ermine, D. Larzul, P. E. Ceccaldi, J. L. Guesdon and H. Tsiang. Polymerase chain reaction amplification of rabies virus nucleic acids from total mouse brain RNA. Molecular and Cell Probes, 4, 1989, 189-191.

[8] K. A. McColl, A. R. Gould, P. W. Seeck, P. T. Hooper, H. A. Westbury and J. S. Smith. Polymerase chain reaction and other laboratory techniques in the diagnosis of long incubation rabies in Australia. Australian Veterinary Journal, 70, 1993, 84-89.

[9] S. A. Nadin-Davis, Polymerase chain reaction protocols for rabies virus discrimination. Journal of Virological Methods, 75, 1998, $1-8$.

[10] G. J. Hughes, J. S. Smith, C. A. Hanlon and C. E. Rupprecht. Evaluation of a Taq-Man PCR assay to detect rabies virus RNA: influence of sequence variation and application to quantification of viral loads. Journal of Clinical Microbiology, 42, 2004, 299306.

[11] D. Sacramento, H. Bourhy and N. Tordo. PCR technique as an alternative method for diagnosis and molecular epidemiology of rabies virus. Molecular and Cell Probes, 5, 1991, 229-240. 